\title{
KONEKTIVITAS PELAYARAN PERINTIS SEBAGAI BAGIAN SISTEM DISTRIBUSI LOGISTIK DALAM MENDUKUNG KEBERHASILAN TOL LAUT
}

\author{
* Primadi Candra Susanto ${ }^{1}$, Yosi Pahala ${ }^{2}$, Tri Mulyani Setyowati ${ }^{3}$ \\ ${ }^{1,2,3}$ Institut Transportasi dan Logistik Trisakti, Jakarta, Indonesia
}

*Email Korespondensi:

primstrisakti@gmail.com

\section{ARTIKEL INFORMASI}

Diterima:

25 Juni 2021

Direvisi:

12 Juli 2021

Dipublikasi:

22 Juli 2021

\section{ABSTRAK}

Tujuan dari penelitian ini adalah untuk membahas keberhasilan penerapan Tol Laut, Tol Laut merupakan sebuah konsep untuk meningkatkan proses transportasi logistik di Indonesia, sehingga diharapkan proses distribusi barang (khususnya makanan) di Indonesia dapat berjalan dengan lancar. menjadi lebih mudah dan kemudian berdampak pada harga bahan pokok yang lebih merata di seluruh Indonesia. Metode penelitian dengan metode kuantitatif yang lebih menekankan pada data yang diolah dengan menyebarkan kuesioner kepada pihak-pihak yang terlibat dalam penyelenggaraan Tol Laut antara lain perusahaan pelayaran, perusahaan bongkar muat, perusahaan freight forwarding, perusahaan armada angkutan dan pemasok barang. Gagasan tol laut tidak hanya membahas masalah pelayanan transportasi laut untuk rute tertentu dari barat ke wilayah tengah dan timur dengan menggunakan kapal dengan ukuran yang relatif besar tetapi juga harus memikirkan rantai pasokan dan distribusi kargo. untuk diangkut melalui transportasi laut dan tentunya juga harus memperhatikan kondisi dan kapasitas pelabuhan yang akan disinggahi beserta fasilitas dan akses jalan dan dapat dikatakan manfaat utamanya adalah terselenggaranya program laut, yang mampu menyetarakan harga bahan pokok di seluruh wilayah Indonesia.

Kata Kunci: Konektivitas; Pelayaran Perintis; Distribusi Logistik; Disparitas Harga

\section{PENDAHULUAN}

Pemerintah telah mencanangkan Program Tol Laut yang dilatarbelakangi disparitas harga yang cukup tinggi antara wilayah barat dan timur Indonesia. Pertumbuhan ekonomi yang terpusat di Pulau Jawa mengakibatkan inefisiensi transportasi laut di Indonesia karena ketidakseimbangan muatan balik dari wilayahwilayah yang pertumbuhan ekonominya rendah, khususnya di Kawasan Timur Indonesia. Pemerintah telah menetapkan beberapa dasar hukum Program Tol Laut, antara lain Perpres No. 106 Tahun 2015 tentang Penyelenggaraan Kewajiban Publik untuk Angkutan Barang di Laut dan Permenhub No. PM. 4 Tahun 2016 tentang Perubahan Atas Peraturan Menteri Perhubungan No. PM 161 Tahun 2015 tentang Penyelenggaraan Kewajiban Pelayanan Publik untuk Angkutan Barang di Laut. 
Pemerintah telah menetapkan enam trayek tol laut tahap pertama dengan SK AL.108/7/8/DJPL-15 tentang Jaringan Trayek Pelayaran Tol Laut Tahun Anggaran 2016 dan Ketentuan-Ketentuan Pelaksanaannya. Selain itu, ditetapkan juga Permenhub No. 10 Tahun 2016 tentang Tarif Angkutan Barang di Laut dalam Rangka Pelaksanaan Kewajiban Pelayanan Publik (Public Service Obligation).

Index Harga Konsumen dan Inflasi Bulanan Kaitan Dengan Disparitas Harga, sumber Badan Pusat Statistik, pelayanan dan harga yang selama ini diberikan sangat berpengaruh terhadap loyalitas pelanggan kepada Perusahaan. Melihat dari data diatas terlihat bahwa Loyalitas pelanggan tertinggi ada pada usia Kerjasama 1 tahun, sedangkan terendah ada pada usia Kerjasama 5 tahun yang berarti terdapat kecenderungan penurunan Loyalitas pelanggan, oleh karenanya perlu untuk diketahui bagaimana pengaruh kualitas pelayanan dan Harga baik secara parsial maupun Bersama sama terhadap Loyalitas Pelanggan Perusahaan.

Table 1 Index Harga Konsumen dan Inflasi

\begin{tabular}{ccccccccccc}
\hline & \multicolumn{2}{c}{2015} & \multicolumn{2}{c}{2016} & \multicolumn{2}{c}{2017} & \multicolumn{2}{c}{2018} & \multicolumn{2}{c}{2019} \\
\cline { 2 - 10 } Bulan & IHK & Inflasi & IHK & Inflasi & IHK & Inflasi & IHK & Inflasi & IHK & Inflasi \\
\hline Jan & 118,71 & $-0,24$ & 123,62 & 0,51 & 127,94 & 0,97 & 132,10 & 0,62 & 135,83 & 0,32 \\
\hline Feb & 118,28 & $-0,36$ & 123,51 & $-0,09$ & 128,24 & 0,23 & 132,32 & 0,17 & 135,72 & $-0,08$ \\
\hline Mar & 118,48 & 0,17 & 123,75 & 0,19 & 128,22 & $-0,02$ & 132,58 & 0,020 & 135,87 & 0,11 \\
\hline Apr & 118,91 & 0,36 & 123,19 & $-0,45$ & 128,33 & 0,09 & 132,71 & 0,10 & 136,47 & 0,44 \\
\hline Mei & 119,50 & 0,50 & 123,48 & 0,24 & 128,83 & 0,39 & 132,99 & 0,21 & 137,40 & 0,68 \\
\hline Jun & 120,14 & 0,54 & 124,29 & 0,66 & 129,72 & 0,69 & 133,77 & 0,59 & 138,16 & 0,55 \\
\hline Jul & 121,26 & 0,94 & 125,15 & 0,69 & 130,00 & 0,22 & 134,14 & 0,28 & 138,59 & 0,31 \\
\hline Ags & 121,73 & 0,39 & 125,13 & $-0,02$ & 129,91 & $-0,07$ & 134,07 & $-0,005$ & 138,75 & 0,12 \\
\hline Sept & 121,67 & $-0,05$ & 125,13 & 0,22 & 130,08 & 0,13 & 133,83 & $-0,18$ & 138,37 & $-0,27$ \\
\hline Okt & 121,57 & $-0,08$ & 125,59 & 0,14 & 130,09 & 0,01 & 134,2 & 0,28 & 138,4 & 0,02 \\
\hline Nov & 121,82 & 0,21 & 126,18 & 0,47 & 130,35 & 0,2 & 134,56 & 0,27 & 138,6 & 0,14 \\
\hline Des & 122,99 & 0,96 & 126,71 & 0,42 & 131,28 & 0,71 & 135,39 & 0,62 & & \\
\hline Tingkat Inflasi & & $\mathbf{3 , 3 5}$ & & $\mathbf{3 , 0 2}$ & & $\mathbf{3 , 6 1}$ & & $\mathbf{3 , 1 3}$ & & $\mathbf{2 , 3 7}$ \\
\hline
\end{tabular}

Sumber: Badan Pusat Statistik Indonesia

Kapal yang digunakan melintasi tol laut adalah kapal dengan kapasitas dan volume sangat besar. Ini demi termuatnya sebanyak-banykanya pasokan komoditas hingga mencapai daerah 3TP (Terluar, Terdepan, Tertinggal, dan Perbatasan) yang dituju. Berikut ini adalah jalur tol laut Indonesia:

Tabel 2. Rute Trayek Tol Laut Indonesia Rute Trayek Tol Laut Indonesia

\begin{tabular}{cccccc}
\multicolumn{7}{c}{ Rute Trayek Tol Laut Indonesia } & \\
\hline Rute 1 & Rute 2 & Rute 3 & Rute 4 & Rute 5 & Rute 6 \\
\hline Tanjung Perak & Tanjung Perak & Tanjung Perak & Tanjung Priok & Makasar & Tanjung Priok \\
\hline Wanci & Kalabahi & Larantuka & Makasar & Tahuna & Terempa \\
\hline Namlea & Moa & Lewo Leba & Manok Wari & Lirung & Natuna \\
\hline Fak-Fak & Saumlaki & Rote & Wasior & Morotai & - \\
\hline Kaimana & Dobo & Sabu & Nabire & Tobelo & - \\
\hline Timika & Marauke & Waingapu & Serui & Ternate & - \\
\hline- & - & - & Biak & Babang & - \\
\hline
\end{tabular}

Sumber: CNBC Media (2019)

Tentunya sudah sangat jelas kapal yang digunakan untuk melintasi tol laut adalah kapal yang memiliki kapasitas dan volume sangat besar. Selain agar/penting sekali pengangkutan dapat dimaksimalkan untuk mengirim barang dalam jumlah besar, kapal tol laut juga harus mampu melintasi laut yang memiliki jarak yang cukup jauh. Implementasi Program Tol Laut tersebut berbeda dengan konsep awal Tol Laut yang direncanakan dalam bentuk pelayaran dari barat ke timur Indonesia dan sebaliknya dengan menggunakan kapal berkapasitas besar secara terjadwal. Pemerintah perlu segera merancang dan menetapkan rencana induk (master plan) Tol Laut. Rencana induk diperlukan sebagai acuan kementerian/lembaga terkait dalam mengimplementasikan Tol 
Laut. Acuan ini juga diperlukan bagi para pelaku dan para pihak (stakeholders) lainnya untuk terlibat dalam Program Tol Laut, termasuk perusahaan-perusahaan pelayaran.

Perencanaan rute harus mempertimbangkan arus dan volume barang antar wilayah, termasuk potensi setiap wilayah. Perencanaan ini bersifat jangka menengah dan panjang sehingga harus terintegrasi dengan rencana kementerian terkait, seperti Rencana Induk Pembangunan Industri Nasional (RIPIN) 2015-2035 dan Sistem Logistik Ikan Nasional (SLIN) dari Kementerian Kelautan dan Perikanan. Perencananaan Program Tol Laut harus terintegrasi dan sinergi dengan rencana pembangunan wilayah, baik terkait dengan rencana pengembangan komoditas unggulan maupun Rencana Tata Ruang Wilayah (RTRW) masing-masing. Karakteristik komoditas wilayah akan menentukan infrastruktur fisik dan suprastruktur pelabuhan. Tol Laut hendaknya melibatkan pelayaran nasional, baik perusahaan BUMN maupun swasta. Kegiatan operasional Tol Laut perlu diintegrasikan dengan pelayaran yang sudah berjalan, termasuk dengan Pelayaran Rakyat. Pengembangan Tol Laut juga harus terintegrasi dengan sistem transportasi hinterland masing-masing wilayah. Integrasi mencakup dukungan infrastruktur transportasi (jalan dan rel kereta api) dan para pelakunya (perusahaan jasa transportasi sebagai feeder).

Tabel 3 Disparitas Harga Sembako

\begin{tabular}{|c|c|c|c|c|}
\hline \multicolumn{5}{|c|}{ Daging Ayam } \\
\hline \multirow{2}{*}{ Daerah } & \multicolumn{2}{|c|}{ Harga Rata-Rata } & \multicolumn{2}{|c|}{ Disparitas } \\
\hline & 2016 & 2018 & 2016 & 2018 \\
\hline Jakarta & Rp 30,325 & Rp 36,329 & $\operatorname{Rp} \quad(2,492)$ & $\mathrm{Rp} \quad 1,233$ \\
\hline Kupang & Rp 37,350 & Rp 47,921 & 4,533 & Rp 12,825 \\
\hline Papua & Rp 37,425 & Rp 41,158 & 4,608 & 6,063 \\
\hline Maluku & Rp 35,708 & Rp 43,500 & 2,892 & 8,404 \\
\hline Nasional & Rp 32,817 & Rp 35,096 & - & - \\
\hline \multicolumn{5}{|c|}{ Cabai Rawit } \\
\hline \multirow{2}{*}{ Daerah } & \multicolumn{2}{|c|}{ Harga Rata-Rata } & \multicolumn{2}{|c|}{ Disparitas } \\
\hline & 2016 & 2018 & 2016 & 2018 \\
\hline Jakarta & Rp 46,725 & Rp 42,267 & Rp $\quad 5,925$ & $\mathrm{Rp} \quad 1,417$ \\
\hline Kupang & Rp 33,450 & Rp 40,567 & $(7,350)$ & (283) \\
\hline Papua & Rp 52,192 & Rp 53,800 & 11,392 & Rp 12,950 \\
\hline Maluku & Rp 42,083 & Rp 47,333 & 1,283 & 6,483 \\
\hline Nasional & Rp 40,800 & Rp 40,850 & - & - \\
\hline \multicolumn{5}{|c|}{ Beras } \\
\hline \multirow{2}{*}{ Daerah } & \multicolumn{2}{|c|}{ Harga Rata-Rata } & Disparitas & \\
\hline & 2016 & 2018 & 2016 & 2018 \\
\hline Jakarta & Rp 10,892 & Rp 13,196 & (367) & 1,400 \\
\hline Kupang & Rp 10,850 & 11,646 & $(408)$ & $(150)$ \\
\hline Papua & Rp 11,867 & 12,192 & 608 & 396 \\
\hline Maluku & Rp 12,308 & 12,942 & 1,050 & 1,146 \\
\hline Nasional & Rp 11,258 & 11,796 & - & - \\
\hline
\end{tabular}

Sumber: Pusat Informasi Harga Pangan Stategis Nasional

Operasionalisasi kongkrit dari komitmen tersebut salah satunya ditempuh melalui pengembangan tol laut, sebagai strategi menekan disparitas harga serta memeratakan pembangunan ekonomi berkeadilan di seluruh wilayah Indonesia serta peningkatan konektivitas di daerah terdepan, terluar dan tertinggal. Pilihan strategi pengembangan tol laut sejatinya merupakan elaborasi dari pembangunan inklusif, yang lebih mengedepankan keadilan ekonomi dengan memberikan fokus perhatian lebih kepada wilayah Indonesia yang tertinggal terdepan dan terluar, agar dapat menikmati harga-harga komoditas kebutuhan pokok dan lainnya relatif sama dengan yang dinikmati oleh saudara-saudaranya di wilayah Indonesia lainnya.

Tol laut sebagai sebuah konsep dirancang untuk memperkuat jalur pelayaran yang ditujukan bagi pemerataan pertumbuhan ke Indonesia bagian timur, menurunkan biaya logistik juga menjamin ketersediaan pokok strategis di seluruh wilayah Indonesia dengan harga relatif sama sehingga kesejahteraan rakyat semakin merata. Melalui program tol laut diharapkan akan dapat mempercepat integrasi antara kawasan pelabuhan dengan kawasan industri dan kawasan ekonomi serta kluster-kluster ekonomi untuk menopang kebutuhan akan arus barang dan logistik di pelabuhan. Tol laut juga menjadi salah satu solusi untuk mengatasi kesenjangan antara wilayah Indonesia Barat dengan Indonesia Timur. Karena melalui program ini dikembangkan kawasan 
industri atau kawasan ekonomi baru di sekitar pelabuhan utama maupun pelabuhan pengumpul agar terjadi kesinambungan pengangkutan barang.

Tol laut merupakan suatu bentuk konektivitas laut melalui kapal-kapal besar dari wilayah Indonesia bagian barat menuju Indonesia bagian timur dan sebaliknya secara teratur, terencana, dan kontinyu atau berkelanjutan. Salah satu tujuannya mengatasi masalah disparitas atau perbedaan harga barang satu wilayah dengan wilayah lain. Berdasarkan latar belakang masalah yang telah diuraikan diatas, maka identifikasi masalah dalam penelitian ini adalah ; 1) Keterbatasan industri galangan kapal belum tergarap secara optimal, sehingga berpengaruh terhadap kesiapan armada nasional dalam mengoperasikan tol laut, 2) Disparitas harga komoditas masih menjadi kendala disebabkan sistem distribusi logistik yang belum terkoneksi dengan Pelabuhan,3) Jenis komoditas yang bervariasi menyebabkan biaya operasional penanganan muatan setiap pelabuhan bereda, 4) Perlu dibukanya jalur pelayaran perintis yang terhubung dengan kawasan ekonomi khusus.

Dalam rumusan masalah penelitian ini dikemukakan pertanyaan penelitian (research question) sebagai berikut: 1) Apakah terdapat pengaruh jumlah armada terhadap disparita harga ; 1) Apakah terdapat pengaruh penetapan tariff terhadap disparitas harga, 2) Apakah terdapat pengaruh sistem distribusi logistik terhadap disparitas harga, 3) Apakah terdapat pengaruh jenis komoditas terhadap disparitas harga, 4)Apakah terdapat pengaruh jumlah arm ada secara, penetapan tariff, sistem distribusi logistik dan jenis komoditas secara bersama terhadap disparitas harga. Penelitian ini dilakukan dengan tujuan penelitian adalah ; 1) Untuk mengetahui pengaruh jumlah armada terhadap disparita harga, 2) Untuk mengetahui pengaruh penetapan tariff terhadap disparitas harga, 3) Untuk mengetahui pengaruh sistem distribusi logistik terhadap disparitas harga, 4) Untuk mengetahui pengaruh jenis komoditas terhadap disparitas harga, 5) Untuk mengetahui pengaruh jumlah armada secara, penetapan tariff, sistem distribusi logistik dan jenis komoditas secara bersama terhadap disparitas harga.

\section{KAJIAN PUSTAKA}

Penelitian tentang keberhasilan Tol Laut di Indonesia masih jarang dilakukan, terutama di sektor pelayaran atau transportasi laut. Namun untuk memperlihatkan state of the art dari studi yang dilakukan, maka penulis akan memaparkan beberapa penelitian yang dipandang relevan untuk menggambarkan kajian mendukung keberhasilan tol laut.

Daftar judul penelitian sebelumnya terkait Tol Laut:

Tabel 4. Judul Penelitian Terdahulu

\begin{tabular}{clc}
\hline No & \multicolumn{1}{c}{ Judul Penelitian } & Tahun \\
\hline 1 & Pelaksanaan Tol Laut PT.Pelni Indoesia Catatan Tentang Tol Laut Jokowi & 2017 \\
\hline 2 & Catatan Tentang Tol Laut Jokowi & 2018 \\
\hline 3 & $\begin{array}{l}\text { Inovasi Teknologi Untuk Mendukung Tol Laut dan Daya Saing Industri } \\
\text { Kapal Nasional }\end{array}$ & 2018 \\
\hline 4 & $\begin{array}{l}\text { Merefungsi Pengangkutan Laut Indonesia Melalui Tol Laut Untuk } \\
\text { Pembangunan Indonesia Timur }\end{array}$ & 2019 \\
\hline 5 & $\begin{array}{l}\text { Strategi Pengembangan Pelayaran Perintis Dengan Analisa SWOT Menuju } \\
\text { Penguatan Program Tol Laut Dengan Poros Maritim Dunia }\end{array}$ & 2019 \\
\hline
\end{tabular}

Peneliti belum menemukan penelitian yang membahas tentang mendukung keberhasilan Tol Laut mendukung keberhasilan Tol Laut (pelayaran) di Indonesia. Kebaruan atau novelty dari penelitian ini juga terletak pada achievements sea highways yang digunakan untuk menganalisis implementasi dari keberhasilan tol laut di Indonesia. Selain itu, secara metode, peneliti menggunakan metode kualitatif dengan Analytical Hierarchy Process (AHP) yang diperoleh melalui observasi dan wawancara mendalam dengan para masyarakat di Indonesia Timur

Menurut Permenhub No. PM 93 tahun 2013 tentang Penyelenggaraan Angkutan Laut, dan/atau wilayah terpencil penyelenggaraan angkutan laut untuk daerah masih tertinggal dilaksanakan oleh menteri, gubernur dan/atau walikota dilaksanakan dengan pelayaran perintis dan penugasan. Kegiatan pelayaran perintis 
diselenggarakan dengan menggunakan kapal yang laik laut barang dan/atau barang dan penumpang. Program tol laut untuk mengangkut penumpang, merupakan bentuk pelayaran perintis dalam pengangkutan barang.

Dalam hal pengangkutan melalui laut, digunakan sarana atau alat transportasi dengan menggunakan kapal laut untuk menghubungkan pulau yang satu dengan pulau yang lainnya dalam memindahkan muatan berupa barang dan maupun orang. Menurut Pasal 310 ayat (1) KUHD kapal laut adalah semua kapal yang dipakai untuk pelayaran dilaut atau yang diperuntukkan untuk itu. Dengan adanya perjanjian tersebut menyebabkan suatu tanggung jawab bagi pengangkut yang terletak pada keamanan dan keselamatan kapal serta muatannya terutama pada saat pelayaran atau selama dalam pengangkutan sebagaimana yang tercantum pada pasal 468 KUHD. Pelayaran Perintis untuk menunjang perekonomian Indonesia, sehingga Pemerintah dapat membuat regulasi- regulasi yang mendukung pelaksanaan Pelayaran Perintis di lapangan yang menyangkut segala aspek dan didukung dengan sarana dan prasarana yang baik serta sumber daya manusia pelaksananya. (Gultom)

Untuk negara kepulauan seperti Indonesia, sistem transportasi laut pelabuhan mempunyai peran penting (Huang et al. 2008). Pelabuhan adalah mode antara sistem transportasi laut dan sistem transportasi darat dalam rangka mendukung dan mengembangkan suatu pembangunan ekonomi suatu wilayah atau negara (Dewa $S$. 2016). Pelabuhan juga merupakan tempat untuk melakukan kegiatan bongkar muat (B/M) komoditas perdagangan (Vis 2003; Steenken et al. 2004), embarkasi dan debarkasi penumpang kapal (Steen Kenetal 2004). Perencanaan dan pengembangan sistem transportasi laut perlu mempertimbangkan dan mengintegrasikan banyak aspek, seperti: layanan kapal di pelabuhan, infrastruktur pelabuhan meliputi; lapangan penumpukan peti kemas, potensi wilayah dan jaringan transportasi darat dari dan ke wilayah hinterland pelabuhan (Notteboom 2009).

Salah satu daerah yang menjadi fokus untuk pengembangan pelabuhan Indonesia yaitu daerah T3P (Terpencil, Terluar, Tertinggal dan Perbatasan) dalam menunjang konektivitas, sebagai contoh pengembangan system pelayaran khusus di daerah T3P (Terpencil, Terluar, Tertinggal dan Perbatasan) yaitu pelayaran perintis dan perencanaan pengembangan pelabuhan di Jayapura, Provinsi Papua, yang merupakan daerah ujung timur Indonesia. Kebijakan Pemerintah Pusat dalam program visi dan misi Nawa Cita lewat Kementerian Perhubungan dan Pemerintah Daerah Provinsi Papua dan Kota Jayapura dalam program tol laut dan poros maritim khususnya bagi pelayaran perintis untuk dalam pengembangan kawasan pelabuhan Jayapura, diharapkan dapat memberikan dampak positif bagi perkembangan Kota Jayapura sebagai Ibu Kota Provinsi Papua dan juga terlebih khusus dapat melayani kapal-kapal niaga yang akan beroperasi pada pelayaran perintis dengan rute terpencil, terluar, tertinggal dan perbatasan dalam menunjang konektivitas, pengembangan sarana dan prasarana pelabuhan perintis agar dapat menunjang segala aktivitas dan efisiensi pelabuhan, pengembangan wilayah hinterland untuk memaksimalkan fungsi pelayaran perintis yang sibuk dan padat. (Willem Thobias, 2019)

Bertambahnya kapasitas muat serta kecepatan mempengaruhi peningkatan proses distribusi penumpang maupun barang serta waktu berlayar sehingga dapat dicapai tingkat efesiensi dari segi total biaya Untuk lebih meningkatkan tingkat optimalisasi kinerja system distribusi jaringan transportasi laut perlu dilakukan analisa lanjut menyangkut trayek yang ada dengan melakukan pemodelan atau penataan trayek guna mendapatkan trayek atau rute yang lebih optimal berdasarkan karakteristik wilayah, pola pergerakan serta kontribusi pada tiap pelabuhan yang ada. (Standy Johannes,2012)

Banyak usaha untuk mendukung konsep tol laut, yang sesuai draf rencana disusun oleh Badan Perencanaan Pembangunan Nasional (Bappenas), yaitu akan dibangun 24 pelabuhan strategis. Pelabuhan tersebut terbagi atas pelabuhan yang bertugas menjadi penghubung hubungan internasional, pelabuhan utama, dan pelabuhan pengumpul.

Konsep Tol Laut merupakan rute tranportasi laut mulai dari Sumatera sampai Papua dengan melewati semua pelabuhan utama di Indonesia. Jalur laut mampu menjadi alternative di tengah tingginya beban pengangkutan yang selama ini bertumpu pada jalur darat maupun jalur kereta api. Tol Laut dapat menunjang pengangkutan laut untuk mendukung perekonomian Indonesia kawasan Timur yaitu Papua (Elfrida).

Sebuah konsep konektivitas dan distribusi logistik nasional dan perdagangan antar pulau untuk mendukung program MP3EI yang disebut "Pendulum Nusantara", yang menghubungkan pelabuhan-pelabuhan utama dengan rute dari Belawan hingga Sorong, dan ditunjang dengan rute-rute feeder dan perintis. Konsep ini pada dasarnya sama dengan program "Tol Laut" seperti yang dicanangkan presiden terpilih tahun 2014-2019. dimana program ini membutuhkan penyediaan infrastruktur dan armada kapal yang cukup besar untuk 
meningkatkan konektivitas logistik nasional dan mempercepat pemerataan pembangunan. (Maaruf Buana, 2014)

Kebijakan pengendalian manajemen distribusi logistik akan berpengaruh dengan meningkat performa kinerja perusahaan dalam mendistribusikan permintaan ke gerai pelanggan dan mengatur persediaan produk di pusat distribusi. Sejalan dengan filosofi distribusi logistik yang menghendaki integrasi antara sistem, pengukuran kinerja pada distribusi logistik dirancang berdasarkan proses (proces-based). Proses adalah kumpulan dari aktivitas yang melintasi waktu dan tempat,memiliki awal, akhir dan input maupun output yang jelas. Pengelolaan persediaan yang baik dan model transportasi yang tepat akan dapat meningkatkan performance dari distribusi logistik dalam rantai pasok. Penelitian ini mengusulkan sistem pengendalian persediaan dan distribusi yang disebut sistem perencanaan persediaan dan distribusi atau IDP (inventory distribution plan). (Afridel, 2013)

Kinerja distribusi logistik Disribusi merupakan salah satu aktivitas logistik pada sisi outbond, dengan kinerja distribusi dapat diukur dapat berupa pengiriman tepat waktu, yang menunjukan kesempurnaan terjadinya pengiriman, dan mencerminkan tingkat pelayanan pelanggan. Stewart (1995) mengidentifikasi ukuran kinerja distribusi yaitu : tingkat pemenuhan pesanan, pengiriman sesuai due date, pemenuhan urutan lead-time pemesanan, jumlah faktur sempurna, dan fleksibilitas sistem pengiriman untuk memenuhi kebutuhan pelanggan tertentu serta produktivitas. Konstruk kinerja distribusi logistik dalam penelitian ini terdiri dari 6 indikator.

Sistem logistik nasional perlu produk didorong untuk menghasilkan berkualitas dengan harga yang bersaing. Upaya yang mendasar untuk mendorong meningkatkannya kinerja logistik nasional diperlukan menghilangkan berbagai logistik sektor yaitu dalam hambatan koordinasi antar lembaga terkait sistem logistik nasional yang terpadu, sumber daya manusia sektor logistik yang profesional, di muat proses bongkar mengurangi biaya tinggi pelabuhan yang membuat (high cost), meningkatkan pemenuhan investasi dalam infrastruktur di pelabuhan untuk proses bongkar muat, memperpendek proses perizinan, dan penggunaan teknologi informasi dalam meningkatkan kinerja logistik. (Budi Sitorus, 2017)

Logistik merupakan Manajemen salah satu aktivitas menitikberatkan pada barang melalui cara untuk mengelola penentuan dan perencanaan tindakan kebutuhan, pengadaan, penyimpanan, penyaluran, pemeliharaan dan penghapusan untuk mencapai tujuan yang telah Selain manajemen ditetapkan. logistik, perlu untuk diketahui Manajemen Rantai Pasokan (Supply Chain Managgement), adapun pendapat para ahli terkait dengan logistik dan manajemen rantai pasokan sebagai berikut : (Kerin, Hartley, dan Rudelius, 2000)

Logistik melibatkan kegiatan-kegiatan yang fokus untuk mendapatkan jumlah yang tepat dari produk yang tepat (of the right products) ke tempat yang tepat (to the right place) pada waktu yang tepat (at the right time) pada biaya yang rendah (at the lowest possible cost) David Blanchard (2010),

Supply chain management (SCM) is the management of a network of interconnected businesses involved in the provision of product and service packages required by the end customers in a supply chain. Supply chain management spans all movement and storage of raw materials, work-in-process inventory, and finished goods from point of origin to point of consumption. (David Blanchard 2010)

Tujuan dari logistik (Bowersox,2002) adalah menyampaikan barang jadi dan bermacam-macam material dalam jumlah yang tepat pada waktu yang dibutuhkan, dan dengan total biaya yang terendah. Melalui material kompleks, proses logistiklah material yang sangat luas dari negara industri dan produk-produk didistribusikan melalui saluran-saluran distribusi untuk logsitik konsumen. Penyelenggaraan memberikan kegunaan (utility) waktu dan tempat. Kegunaan tersebut merupakan aspek penting dari operasi perusahaan dan utama, yaitu (1) Order processing, termasuk informasi yang sangat kuat tentang aliran sistem logistik dan jumlah operasi. (2) Inventory management, bagaimana mengatur penimbunan barang yang akan diproduksi, dikirim dan dijual. (3) Freight transportation, sangat berpengaruh di bidang perekonomian, karena transportasi muatan biasanya mempunyai perbedaan jarak yang sangat jauh antara satu tempat dengan yang lainnya.

Program tol laut dilatar belakangi karena adanya disparitas harga yang cukup tinggi antara wilayah barat dan timur Indonesia. Banyaknya daerah di wilayah timur Indonesia yang belum berkembang sehingga dibutuhkan sarana transportasi untuk mendistribusikan barang pokok dan 2015) dari daerah yang sudah Nomor 71 Tahun Presiden penting (Peraturan barang berkembang/maju. Perbandingan PDB Kawasan Timur Indonesia dan Kawasan Barat Indonesia yaitu 18,6\% berbanding 81,4\%. Konsep Tol Laut adalah konektivitas laut yang efektif berupa adanya kapal yang melayari secara rutin dan terjadwal dari barat sampai ke timur.

Sub kriteria yang menjadi prioritas paling tinggi adalah disparitas harga karena karena salah satu tujuan dari program tol laut adalah mengurangi disparitas harga. Disparitas harga terjadi karena adanya akumulasi 
besarnya biaya yang dikeluarkan dalam distribusi barang dari asal ke tujuan, biaya tersebut mencakup harga pokok barang, biaya pengiriman dan biaya distribusi, selama ini barang dikirim melalui laut dimana keterbatasan muatan balik menyebabkan biaya kapal kembali ke pelabuhan asal dibebankan kepada konsumen. Indikator kesuksesan program tol laut diantaranya adalah penurunan disparitas harga di daerah tertinggal, terpencil, terluar dan perbatasan. Pemerintah memantau secara konsisten terhadap disparitas harga di daerah yang telah dilalui kapal tol laut. Program tol laut telah berhasil menekan disparitas harga di Indonesia bagian timur sekitar 20-25\% (Panjaitan LB 2017).

Tol laut yang dimaksud merupakan infrastruktur berupa pelabuhan dan transport laut. Tidak seperti tol jalan darat, semua perairan yang tidak terlalu dangkal di laut dapat dilalui kapal. Sehingga tol laut itu jalurjalur transportasi laut tertentu dengan pelabuhan-pelabuhan yang tertentu beroperasi secara reguler. Kunci dari tol laut adalah konektivitas melalui jalan laut. Untuk itu pembangunan tol laut dari barat ke timur, timur ke barat, yang menghubungkan konektivitas antara pulau dengan pulau, dapat menurunkan biaya transportasi sehingga biaya logistik juga akan turun. (Budi Santoso). Peluang kerja dan kesempatan berusaha menjadi terbuka, produktivitas dan daya saing diprediksi akan mengalami peningkatan dan biaya logistik akan turun sehingga harga-harga barang semakin murah sehingga beban masyarakat di Indonesia timur bisa dikurangi dan dapat memberikan kemudahan distribusi barang dan logistik, menurunkan biaya logistik dan akan menekan tingginya harga. (Dian Junita Arisusanty, 2018).

\section{Hubungan konektivitas pelayaran perintis dengan tol laut}

Konektivitas pelayaran perintis adalah salah satu kunci dalam meningkatkan dan mengembangkan ekonomi kawasan yang berhubungan dengan berbagai infrastruktur terkait. Penyelenggaraan pelayaran printis harus bisa berjalan lebih efisien dan inovatif, dengan harapan jika pelayaran perintis bisa lebih efisiensi tentunya akan meningkatkan produktivitas dan mendorong pembiayaan penyelenggaraan angkutan laut perintis yang efisien, inovatif, dan berkelanjutan. Tol Laut dapat menghasilkan solusi agar pelayanan kapal perintis tidak terputus meskipun kapal yang melayani trayek tersebut masuk perawatan atau docking. Bila kapal perintis masuk docking, pelayanan kepada masyarakat sering mengalami hambatan karena ketidaktersediaan kapal pengganti.

\section{Hubungan sistem distribusi logistik dengan keberhasilan tol laut}

Pengertian distribusi dan logistik merupakan dua hal yang berbeda namun berkaitan erat. Keduanya sama-sama memiliki peran penting dalam bidang usaha. Baik dalam manufaktur maupun industri, keduanya berkontribusi besar. Usaha dalam bentuk penjualan barang maupun jasa akan membutuhkan peran baik dari logistik maupun distribusi. Arti distribusi dan logistik tak lepas dari manajemen sebuah perusahaan. Distribusi bisa diartikan sebagai saluran yang bisa digunakan oleh produsen untuk menyampaikan barang maupun layanan jasa mereka kepada konsumen. Maka kita mengenal istilah distributor yang siap melakukan tugas tersebut.

Sedangkan logistik memiliki arti yang berbeda. Istilah ini bisa diartikan sebagai pengendalian arus material, barang jadi maupun informasi yang berkaitan dengan bidang usaha. Logistik ada hubungannya dengan distribusi. Dalam logistik ada perencanaan dan pengendalian arus material, barang mulai dari pabrik atau produsen hingga ke konsumen. Distribusi barang yang dilakukan melalui kapal tol laut harus di lakukan transpransi dengan menggunakan "No Service, No Pay". Ke depannya semua biaya yang dikenakan kepada pengiriman barang melalui program Tol Laut bisa diketahui dari gudang pengirim barang sampai dengan konsumen di daerah terpencil, sehingga harga jual barang yang diangkut dengan subsidi kewajiban pelayanan publik bisa ditentukan dan mudah dikendalikan dalam meningkatkan konektivitas dan pelaksanaan program tol laut serta meningkatkan pemerataan ekonomi di wilayah wilayah yang masih tertinggal, terluar dan belum berkembang. Biaya logistik yang tinggi khususnya di moda transportasi laut, tampaknya menjadi sebuah persoalan serius bangsa ini, apalagi dengan kondisi geografis sebagai negara kepulauan, mengoptimalkan transportasi laut menjadi sebuah pilihan yang tepat, dengan adanya tol laut dan peningkatan konektivitas secara keseluruhan, pemerintah berharap sistem logistik nasional menjadi lebih baik dan biaya logistik dapat dikurangi secara signifikan.

Melalui program Tol Laut diharapkan akan dapat mempercepatat integrasi antara kawasan pelabuhan dengan kawasan industri dan kawasan ekonomi, kawasan pertumbuhan ekonomi serta kluster-kluster ekonomi untuk menopang kebutuhan akan arus barang dan logistik di pelabuhan. Tol laut juga menjadi salah satu solusi untuk mengatasi kesenjangan antara wilayah Indonesia Barat dengan Indonesia Timur. Karena melalui 
program ini dikembangkan kawasan industri atau kawasan ekonomi baru di sekitar pelabuhan utama maupun pelabuhan pengumpul, agar terjadi keseimbangan pengangkutan barang. Berdasarkan penjelasan di atas maka peneliti menyusun konstelasi variabel eksogen dalam penelitian ini yaitu; jumlah armada, penetapan tarif, sistem distribusi logistik dan jenis komoditas sebagai variabel pelayanan tol laut khususnya angkutan perintis yang dapat mempengaruhi disparitas harga sebagai variabel endogen untuk mencapai keberhasilan tol laut.

Berikut konstelasi variabel penelitian.

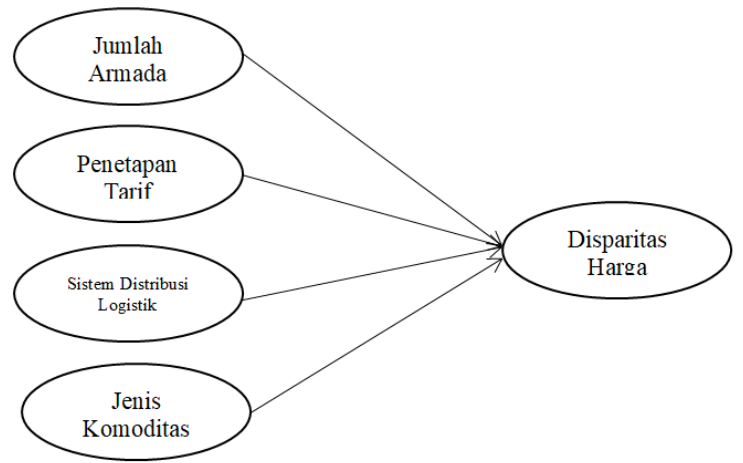

Gambar 1. Kerangka Berpikir

Keterangan:

$\mathrm{X}_{1}$ : Jumlah Armada

$\mathrm{X}_{2}$ : Penetapan Tarif

$\mathrm{X}_{3}$ : Sistem Distribusi Logistik

$\mathrm{X}_{4}$ : Jenis Komoditas

Y : Disparitas Harga

Berdasarkan teori dan kerangka berfikir yang dikemukakan diatas, maka hipotesis dalam penelitian ini dapat dirumuskan sebagai berikut:

H1: Diduga terdapat pengaruh antara jumlah armada terhadap disparita harga.

H2: Diduga terdapat pengaruh antara penetapan tariff terhadap disparitas harga.

H3: Diduga terdapat pengaruh antara sistem distribusi logistik terhadap disparitas harga.

H4: Diduga terdapat pengaruh antara jenis komoditas terhadap disparitas harga.

H5: Diduga terdapat pengaruh jumlah armada secara, penetapan tariff, sistem distribusi logistik dan jenis komoditas secara bersama terhadap disparitas harga.

\section{METODE}

Dalam penelitian ini, data yang digunakan merupakan data primer yang didapat dari hasil wawancara (indepth interview) dengan pakar dan praktisi, yang memilki pemahaman tentang permasalahan di bahas Selanjutnya menyusun kuesioner dan dilanjutkan kembali dengan pengisian kuesioner pada pertemuan kedua dengan responden. Secara umum penelitian ini bertujuan untuk memperoleh kejelasan mengenai variabelvariabel yang dapat mempengaruhi keberhasilan Tol Laut. Sedangkan secara khusus kegiatan penelitian ini bertujuan untuk mengetahui dan mengalisis sesuai dengan identifikasi dan perumusan masalah.

Berdasarkan hal tersebut, maka metode penelitian yang digunakan dalam penelitian ini adalah metode penelitian survey dengan taraf penjelasan deskriptif dan teknik analisa yang digunakan analisa data kuantitatif yang didukung data kualitatif. Karakteristik yang akan diuji dalam penelitian ini adalah konektivitas pelayaran perintis dan sitem distribusi logistik yang diduga berpengaruh secara positif dan signifikan terhadap dalam mendukung keberhasilan tol laut. Sampel dalam penelitian ini adalah pengguna dalam pelayanan jasa pelayaran tol laut yang terdiri dari operator tol laut, pemilik barang (freight forwarding) perusahaan bongkar muat dan perusahaan ekspedisi kapal laut (EMKL) pada pelayaran tol laut yang memiliki homogenitas..

\section{HASIL DAN PEMBAHASAN}


Hasil pengujian hipotesis dan pembahasan terhadap uji hipotesis yang diuji secara statistik dengan menggunakan aplikasi software SmartPLS 3.0 dan uji karakteristik responden dan analisa statistik deskriptif data menggunakan SPSS versi 28. Nilai akar kuadrat AVE untuk masing-masingkonstruk lebih besar daripada nilai korelasinya dengan nilai selisih yang sangat tipis bahkan hampir sama dengan korelasinya sehingga konstruk dalam model penelitian ini masih dapat dikatakan memiliki discriminant validity yang cukup baik.

Model penelitian menghasilkan nilai composite reliability untuk semua konstruk berada diatas nilai 0.70 . Dengan nilai yang dihasilkan tersebut, semua konstruk memiliki reliabilitas yang baik sesuai dengan batasnilai minumun yang telah disyaratkan. Nilai Cronbach's Alpha untuk konstuak variable Jenis Komoditas, Jumlah Armada dan Sistem Distribusi Logistik berada diatas nilai 0.70, sedangkan nilai Cronbach's Alpha untuk konstruk variable Disparitas Harga dan Penetapan Tarif memiliki nilai dibawah 0,70 tetapi mendekati angka 0.70, sehingga dibulatkan ke atas menjadi 0.70. Dengan nilai yang dihasilkan tersebut, semua konstrak memiliki reliabilitas yang cukup baik dapat dikatakan reliable.

Jenis Komoditas, Jumlah Armada, Penetapan Tarif dan Sistem Distribusi Logistik terhadap Disparitas Harga memiliki nilai VIF kurang dari 10 bahkan masih dalam kisaran interval 2-4, maka dalam model penelitian tersebut dapat dinyatakan tidak terjadi multikolinearitas. Jenis Komoditas, Jumlah Armada, Penetapan Tarif dan Sistem Distribusi Logistik mampu menjelaskan variabilitas konstruk Disparitas Harga sebesar $76 \%$, dan sisanya sebesar $24 \%$ diterangkan oleh konstuk lainnya diluar modeldalam penelitian ini.

Nilai f-square di atas, efek size yang dapat di kategorikan besar pengaruh Jumlah Armada terhadap Disparitas Harga dengan kategori kuat di atas nilai 0.35, sedangkan untuk kategori efek size yang lemah terdapat pada Sistem Distribusi Logistik dengan nilai di bawah nilai 0,02. Selanjutnya nilai Penetarapan Tarif sebesar 0,208 dan Jenis Komoditas mempunya nilai 0,097 masih dikategorikan kuat karena mempunyai nilai di atas 0,02. Dari hasil perhitungan berdasarkan persamaan di atas nilai dari goodness of Fit (GoF) dalam model penelitian ini adalah 0,6586 , secara keseluruhan model penelitian inimemiliki performa gabungan yang lebih tinggi dari skala 0-1 yang terbagi menjadi GoF kecil $=0,1$, GoF medium $=0,25$ dan GoF besar $=0,38$. Dengan nilai perhitungan tersebut dapat di simpulkan bahwa model atau performa hubungan antara outter dan inner model ini fit atau valid. Nilai dari $\mathrm{Q}^{2}$ predictive relevance 0,422 menunjukkan bahwa nilai $\mathrm{Q}^{2}>0$ menunjukkan bukti bahwa nilai-nilai yang diobservasi sudah direkonstruksi dengan baik dengan demikian model mempunyai relevansi prediktif.

\section{Pengujian Hipotesis}

Pengujian Hipotesis dapat dilakukan setelah mendapatkan hasil pengujian innermodel (model struktural) dan outer model (measurement model) yang meliputi output R-square, Gof, validitas konvergen, validitas diskriminan dan composite reliability. Untuk melihat apakah suatu hipotesis itu dapat diterima atau ditolak diantaranya dengan memperhatikan nilai signifikansi antar konstruk, t-statistik, dan p-values. Pengujian hipotesis penelitian ini dilakukan dengan bantuan softw are SmartPLS (Partial Least Square) 3.0. Nilai-nilai tersebut dapat dilihat dari hasil bootstrapping. Rules of thumb yang digunakan pada penelitian ini adalah tstatistik >1,96 dengan tingkat signifikansi p-value 0,05 (5\%) dan koefisien beta bernilai positif. Untuk hasil model penelitian ini dapat digambarkan seperti tampak pada Gambar 6 berikut ini: 


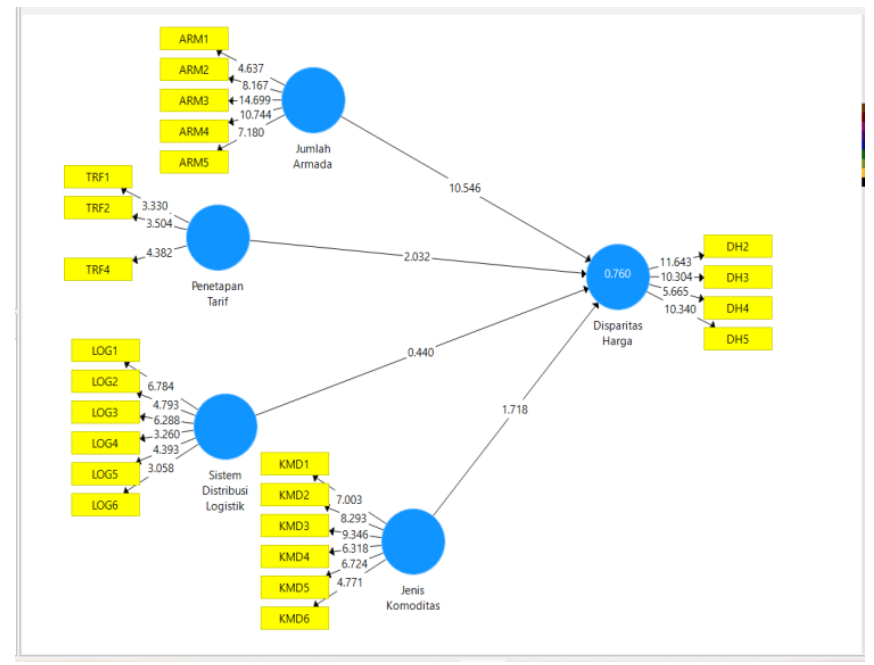

Gambar. 2 Hasil Model Penelitian

Rule of tumbs dari terbentuknya suatu hipotesis penelitian yaitu : (1) jika koefesien atau arah hubungan variabel (ditunjukkan oleh nilai original sample) sejalan dengan yang dihipotesiskan, dan (2) jika nilai $\mathrm{t}$ statistik lebih dari 1,64 (two-tiled) atau 1,96 (one-tiled) dan probability value (p-value) kurang dari 0,05 atau $5 \%$.

Perhitungan untuk uji signifikansi, Hipotesis pertama menguji apakah Jenis Komoditas berpengaruh signifikan terhadap Disparitas Harga. Hasil pengujian menunjukkan bahwa hubungan antara Jenis Komoditas dengan Disparitas Harga adalah tidak signifikan dengan nilai P-Value sebesar 0,092 dan nilai T-statistik sebesar 1,686 (> 1,96). Nilai original sample estimate adalah negatif yaitu sebesar -0.305 yang menunjukkan bahwa arah hubungan antara Jenis Komoditas dengan Disparitas Harga adalah negatif atau berbanding terbalik. Dengan demikian hipotesis H1 dalam penelitian ini yang menyatakan bahwa Jenis Komoditas berpengaruh signifikan terhadap Disparitas Harga ditolak.

Hipotesis kedua menguji apakah Jumlah Armada berpengaruh signifikan terhadap Disparitas Harga. Hasil pengujian menunjukkan bahwa hubungan antara Jumlah Armada dengan Disparitas Harga adalah signifikan dengan nilai P-Value sebesar 0,000 dan nilai T-statistik sebesar 9,931 (> 1,96). Nilai original sample estimate adalah positif yaitu sebesar 0,906 yang menunjukkan bahwa arah hubungan antara Jumlah Armada dengan Disparitas Harga adalah positif atau searah. Dengan demikian hipotesis $\mathrm{H} 2$ dalam penelitian ini yang menyatakan bahwa Jumlah Armada berpengaruh signifikan terhadap Disparitas Harga diterima.

Hipotesis ketiga menguji apakah Penetapan Tarif berpengaruh signifikan terhadap Disparitas Harga. Hasil pengujian menunjukkan bahwa hubungan antara Penetapan Tarif dengan Disparitas Harga adalah signifikan dengan nilai P-Value sebesar 0,048 dan nilai T-statistik sebesar 1,986 (> 1,96). Nilai original sample estimate adalah positif yaitu sebesar 0,320 yang menunjukkan bahwa arah hubungan antara Penetapan Tarif dengan Disparitas Harga adalah positif atau searah. Dengan demikian hipotesis $\mathrm{H} 2$ dalam penelitian ini yang menyatakan bahwa Penetapan Tarif berpengaruh signifikan terhadap Disparitas Harga diterima.

Hipotesis keempat menguji apakah Sistem Distribusi Logistik berpengaruh signifikan terhadap Disparitas Harga. Hasil pengujian menunjukkan bahwa hubungan antara Sistem Distribusi Logistik dengan Disparitas Harga adalah tidak signifikan dengan nilai P-Value sebesar 0,670 dan nilai T-statistik sebesar 0,427 (> 1,96). Nilai original sample estimate adalah negatif yaitu sebesar -0.067 yang menunjukkan bahwa arah hubungan antara Sistem Distribusi Logistik dengan Disparitas Harga adalah negatif atau berbanding terbalik. Dengan demikian hipotesis H1 dalam penelitian ini yang menyatakan bahwa Sistem Distribusi Logistik berpengaruh signifikan terhadap Disparitas Harga ditolak.

Berdasarkan nilai original sample estimate maka diperoleh bahwa variable yang memiliki nilai tertinggi yang mempengaruhi Disparitas Harga adalah pada Jumlah Armada yaitu sebesar 0,960. Hal tersebut menunjukkan bahwa Jumlah Armada mempunyai pengaruh terhadap Disparitas Harga lebih tinggi dari pada ketiga variabel lainnya yaitu Penetapan tarif, Sistem Distribusi Logistik dan Jenis Komoditas. Variabel yang paling tidak dominan pengaruhnya terhadap Disparitas Harga adalah Jenis Komoditas dengan original sample estimate terkecil yaitu sebesar -0,067, dapat dilhat dalam tabel 5 berikut ini : 
Tabel 5. Ringkasan Hasil Pengujian Hipotesis

\begin{tabular}{llcc}
\hline \multicolumn{1}{c}{ Hipotesis } & \multicolumn{1}{c}{ Hasil } & Keterangan \\
\hline H1 & $\begin{array}{l}\text { Jenis Komoditas berpengaruh signifikan } \\
\text { terhadap Disparitas Harga }\end{array}$ & $\begin{array}{c}\text { Koef.Beta }=-0,305 \\
\text { T-Statistics }=1,686 \\
\text { P-value }=0,092\end{array}$ & Ditolak \\
\hline H2 & $\begin{array}{l}\text { Jumlah Armada berpengaruh signifikan } \\
\text { terhadap Disparitas Harga }\end{array}$ & $\begin{array}{c}\text { Koef.Beta }=0,960 \\
\text { T-Statistics }=9,931 \\
\text { P-value }=0,000\end{array}$ & Diterima \\
\hline H3 & $\begin{array}{l}\text { Penetapan Tarif berpengaruh } \\
\text { signifikan terhadap Disparitas }\end{array}$ & $\begin{array}{c}\text { Koef.Beta }=0,320 \\
\text { T-Statistics }=1,986 \\
\text { P-value }=0,048\end{array}$ & Diterima \\
& Harga & $\begin{array}{l}\text { Koef.Beta }=-0,067 \\
\text { T-Statistics }=0,427 \\
\text { P-value }=0,670\end{array}$ & Ditolak \\
H4 $\begin{array}{l}\text { Sistem Distribusi Logistik } \\
\text { berpengaruh signifikan terhadap } \\
\text { Disparitas Harga }\end{array}$ & & \\
\hline
\end{tabular}

Sumber : Data Primer diolah, 2021

\section{Jenis Komoditas terhadap Disparitas}

Jenis Komoditas yang merupakan faktor yang diharapkan mendominasi dalam mensukseskan program pemerintah dalam keberhasilan tol laut dapat meminimalisir terhadap tingginya disparitas harga, sehingga semua sumber daya baik alam maupun manusia antar pulau dan antar darah dapat dimaksimalkan nilai produksi maupun nilai tambahnya bagi peningkatan perekonomian.

Pengujian terhadap hipotesis pertama yaitu apakah Jenis Komoditas berpengaruh signifikan terhadap Disparitas Harga. Hasil pengujian menunjukkan bahwa hubungan antara Jenis Komoditas dengan Disparitas Harga adalah tidak signifikan dengan nilai P-Value sebesar 0,092 dan nilai T-statistik sebesar 1,686 (> 1,96). Nilai original sample estimate adalah negatif yaitu sebesar -0.305 yang menunjukkan bahwa arah hubungan antara Jenis Komoditas dengan Disparitas Harga adalah negatif atau berbanding terbalik. Hal ini mengartikan bahwa apabila terjadi kenaikan dari varian atau jenis komoditas dalam program tol laut ini, maka disparitas harga akan semakin berkurang atau menyempit. Dengan demikian hipotesis H1 dalam penelitian ini yang menyatakan bahwa Jenis Komoditas berpengaruh signifikan terhadap Disparitas Harga ditolak. Hal ini dapat disebabkan karena jenis komoditas yang menjadi objek pengangkutan dalam tol laut ini masih sedikit variannya sehingga belum mencapai optimalisasi, dan diharapkan masih harus menggali atau mengeksplorasi kekayaan sumber daya alam kita yang terdapat di beberapa pulau di Indonesia terutama Indonesia bagian timur supaya dapat memberikan kontribusi maksimal terhadap Pendapatan Perkapita masyarakat maupun Pendapatan Nasional secara agregat, serta disparitas harga dapat dikurangi, sehingga harga-harga barang dan jasa antar pulau tidak terdapat perbedaan harga yang cukup signifikan.

\section{Jumlah Armada tehadap Disparitas Harga}

Ketersediaan jumlah armada yang merupakan alat atau moda transportasi yang terlibat langsung dalam keberhasilan program tol laut ini diharapkan mampu memberikan andil atau sumbangan yang cukup besar terhadap kesuksesan program tol laut ini. Ketersediaan jumlah armada ini diharapkan dapat memaksimalkan fungsi utamanya dalam pengangkutan berbagai komoditas yang terdapat di seluruh pelosok tanah air, sehingga disparitas harga antar pulau dan daerah dapat terkurangi atau teratasi. Pengujian terhadap hipotesis kedua yaitu apakah Jumlah Armada berpengaruh signifikan terhadap Disparitas Harga. Hasil pengujian menunjukkan bahwa hubungan antara Jumlah Armada dengan Disparitas Harga adalah signifikan dengan nilai P-Value sebesar 0,000 dan nilai T-statistik sebesar 9,931 (> 1,96). Nilai original sample estimate adalah positif yaitu sebesar 0,906 yang menunjukkan bahwa arah hubungan antara Jumlah Armada dengan Disparitas Harga adalah positif atau searah. Hal ini mengartikan bahwa apabila ketersediaan jumlah armada dalam pengangkutan tol laut meningkat, maka disparitas harga akan semakin terkurangi atau program tol laut semakin berhasil. Dengan demikian hipotesis $\mathrm{H} 2$ dalam penelitian ini yang menyatakan bahwa Jumlah Armada berpengaruh signifikan terhadap Disparitas Harga diterima.

\section{Penetapan Tarif tehadap Disparitas Harga}


Penetapan tarif tol laut oleh pemerintah diharapkan tidak memberatkan dan dinilai layak (feasible) bagi pengguna tol laut, sehingga diharapkan dapat meningkatkan kuantitas penguna tol laut dan mendukung keberhasilan program tol laut ini yang dicerminkan oleh menurunnya disparitas harga segera tercapai dan pemerataan distribusi pendapatan antar pulau dapat terlaksana dengan baik. Pengujian hipotesis ketiga yaitu apakah Penetapan Tarif berpengaruh signifikan terhadap Disparitas Harga. Hasil pengujian menunjukkan bahwa hubungan antara Penetapan Tarif dengan Disparitas Harga adalah signifikan dengan nilai P-Value sebesar 0,048 dan nilai T-statistik sebesar $1,986(>1,96)$. Nilai original sample estimate adalah positif yaitu sebesar 0,320 yang menunjukkan bahwa arah hubungan antara Penetapan Tarif dengan Disparitas Harga adalah positif atau searah. Hal ini mengartikan bahwa dengan tarif tol laut yang semakin murah atau feasible maka akan meningkatkan keberhasilan tol laut yang dicerminkan oleh disparitas harga semakin menurun atau menyempit. Dengan demikian hipotesis H2 dalam penelitian ini yang menyatakan bahwa Penetapan Tarif berpengaruh signifikan terhadap Disparitas Harga diterima.

\section{Sistem Distribusi Logistik tehadap Disparitas Harga}

Pengujian hipotesis keempat yaitu apakah Sistem Distribusi Logistik berpengaruh signifikan terhadap Disparitas Harga. Hasil pengujian menunjukkan bahwa hubungan antara Sistem Distribusi Logistik dengan Disparitas Harga adalah tidak signifikan dengan nilai P-Value sebesar 0,670 dan nilai T-statistik sebesar 0,427 (> 1,96). Nilai original sample estimate adalah negatif yaitu sebesar -0.067 yang menunjukkan bahwa arah hubungan antara Sistem Distribusi Logistik dengan Disparitas Harga adalah negatif atau berbanding terbalik. Hal ini mengartikan bahwa semakin baiknya sistem distribusi logistik baik dari segi teknologi maupun sistem pengoperasian dalam program tol laut ini, maka akan semakin cepat tercapainya keberhasilan tol laut ini yang dicerminkan oleh semakin menurunnya tingkat dispartitas harga antar pulau dan atar daerah.

Pengujian secara keseluruhan dapat dilihat berdasarkan nilai original sample estimate maka diperoleh bahwa variabel yang memiliki nilai tertinggi yang mempengaruhi Disparitas Harga adalah variabel Jumlah Armada yaitu sebesar 0,960. Hal tersebut menunjukkan bahwa Jumlah Armada mempunyai pengaruh terhadap Disparitas Harga lebih tinggi dari pada ketiga variabel lainnya yaitu Penetapan tarif, Sistem Distribusi Logistik dan Jenis Komoditas. Variabel yang paling tidak dominan pengaruhnya terhadap Disparitas Harga adalah Jenis Komoditas dengan original sample estimate terkecil yaitu sebesar -0,067.

\section{KESIMPLAN DAN SARAN}

Berdasarkan data yang telah didapatkan dan melalui hasil analisis yang telah dilakukan dalam penelitian ini, maka peneliti memberikan kesimpulan atas hasil penelitian ini adalah sebagai berikut:

Penelitian ini membuktikan bahwa berdasarkan nilai P-Value dan T-statistik untuk variabel Jenis Komoditas tidak berpengaruh secara signifikan terhadap Disparitas Harga dan Nilai original sample estimate negatif, hal ini menunjukkan bahwa arah hubungan antara Jenis Komoditas dengan Disparitas Harga adalah negatif atau berbanding terbalik. Hal ini mengandung arti bahwa apabila terjadi kenaikan dari varian atau jenis komoditas dalam program tol laut ini, maka disparitas harga akan semakin berkurang atau menyempit. Tidak signifikannya variabel tersebut dapat disebabkan karena jenis komoditas yang menjadi objek pengangkutan dalam tol laut ini masih sedikit variannya sehingga belum mencapai optimalisasi, dan diharapkan masih harus menggali atau mengeksplorasi kekayaan sumber daya alam kita yang terdapat di beberapa pulau di Indonesia terutama untuk wilayah timur supaya dapat memberikan kontribusi maksimal terhadap Pendapatan Perkapita masyarakat maupun Pendapatan Nasional secara agregat, serta disparitas harga dapat dikurangi, sehingga harga-harga barang dan jasa antar pulau tidak terdapat perbedaan harga yang cukup signifikan,

Penelitian ini membuktikan bahwa berdasarkan nilai P-Value dan T-statistik untuk variabel Jumlah Armada berpengaruh positif dan signifikan terhadap Disparitas Harga, Nilai original sample estimate adalah positif yang menunjukkan bahwa arah hubungan antara Jumlah Armada dengan Disparitas Harga adalah positif atau searah. Hal ini mengandung arti bahwa apabila ketersediaan jumlah armada dalam pengangkutan tol laut meningkat, maka disparitas harga akan semakin terkurangi atau program tol laut semakin berhasil.

Penelitian ini membuktikan bahwa berdasarkan nilai P-Value dan T-statistik untuk variabel Penetapan Tarif berpengaruh positif dan signifikan terhadap Disparitas Harga, Nilai original sample estimate adalah positif yang menunjukkan bahwa arah hubungan antara Penetapan tarif dengan Disparitas Harga adalah positif atau searah. Hal ini mengandung arti bahwa dengan tarif tol laut yang semakin murah atau feasible 
maka akan meningkatkan keberhasilan tol laut yang dicerminkan oleh disparitas harga semakin menurun atau menyempit.

Penelitian ini membuktikan bahwa berdasarkan nilai P-Value dan T-statistik untuk variabel Sistem Distribusi Logistik tidak berpengaruh secara signifikan terhadap Disparitas Harga dan Nilai original sample estimate negatif, hal ini menunjukkan bahwa arah hubungan antara Jenis Komoditas dengan Disparitas Harga adalah negatif atau berbanding terbalik. Hal ini mengandung arti bahwa semakin baiknya sistem distribusi logistik baik dari segi teknologi maupun sistem pengoperasian dalam program tol laut ini, maka akan semakin cepat tercapainya keberhasilan tol laut ini yang dicerminkan oleh semakin menurunnya tingkat dispartitas harga antar pulau dan atar daerah. Hal ini dapat disebabkan oleh kurang optimalnya penggunaan sistem teknologi, masih rendahnya kualitas sumber daya manusia, kurang terintegrasinya pelabuhanpelabuhan terkait dan masih kurangnya kemampuan dari segi permodalan atau pembiayaan karena program tol laut ini merupakan investasi yang membutuhkan modal cukup besar.

Penelitian ini membuktikan bahwa berdasarkan uji f-Square efek size yang paling besar pengaruhnya adalah Jumlah Armada dibandingkan dengan variabel lainnya, berdasarkan uji Goodness of Fit (GoF) secara keseluruhan model penelitian ini memiliki performa gabungan yang tinggi dan dapat di simpulkan bahwa model atau performa hubungan antara outter dan inner model penelitian ini fit atau valid. Sedangkan apabila dilihat dari Nilai dari Q2 predictive relevance yang dihasilkan sebesar 0,42 dengan ukuran apabila nilai Q2 > 0 menunjukkan bukti bahwa nilai-nilai yang diobservasi sudah direkonstruksi dengan baik dengan demikian model mempunyai relevansi prediktif.

Berdasarkan uji determinasi dalam penelitan ini nilai R-square yang dihasilkan sebesar 0,760, mengartikan bahwa Jenis Komoditas, Jumlah Armada, Penetapan Tarif dan Sistem Distribusi Logistik mampu menjelaskan variabilitas konstruk Disparitas Harga sebesar 76\%, dan sisanya sebesar $24 \%$ diterangkan oleh konstuk lainnya diluar model dalam penelitian ini. Hal ini dapat dilakukan penelitian lanjutan atau penelitian pengembangan untuk menjelaskan varibel-variabel lain yang belum dijelaskan dalam peneltian ini untuk menyempurnakan penelitian ini. 


\section{DAFTAR PUSTAKA}

Akdon \& Riduwan. 2010. Rumus dan Data Dalam Analisis Statistika. Bandung: Alfabeta

Ety, Rochaety.2007. Metodologi Penelitian Bisnis Dengan aplikasi SPSS. Jakarta: Mitra Wacana Media

Hermawan, Asep. 2008. Penelitian Bisnis Paradigma Kuantitatif. Jakarta: Grasindo

Sugiyono. 2007. Metode Penelitian Bisnis. Bandung: Alfabeta

Ndhara. 2007. Metode Research Penelitian Ilmiah. Jakarta: Bumi Prakarsa

Prastito, Arif. 2005. Cara Mudah Mengatasi Statistik dan rancangan Percobaan dengan SPSS. Jakarta: Elex Media Komputindo

Riduwan. 2009. Metode dan Teknik Menyusun Proposal Penelitian. Bandung: Alfabeta 2005. Dasar-Dasar Statistika. Bandung: Alfabeta 2010. Metode dan Teknik Menyusun Tesis. Bandung: Alfabeta

Sugiyono. 2007. Metode Penelitian Bisnis Bandung: Alfabeta .2009. Metode Penelitian Kuantitatif Kualitatif dan R\&D. Bandung: Alfabeta

Suparmoko. 2004. Metode Penelitian Praktis. Yogyakarta: BPFE Yogyakarta

Singarimbun, Masri. 2011. Metode Penelitian Survei. Jakarta: Pustaka LP3ES

Sukardi. 2008. Metode Penelitian. Jakarta: Rineka Cipta

Fofid, W. T., Dosen, A., \& Semarang, P. I. P. (2019). Analisa Swot Menuju Penguatan Program Tol Laut Dan Indonesia Sebagai Poros Maritim. 9(2), 2307-2316.

Johannes, S., Anwar, M. R., \& Kurniawan, E. B. (2012). Jumlah Armada Perintis Kabupaten Maluku Barat Daya. 4(167), 119-128.

Panjaitan LB. 2017. Luhut: Tol Laut Tekan Disparitas Harga 25 Persen [internet]. [diacu 2017 Mei 04]. Tersedia dari: http://www.republika.co.id/berita/ekonomi/makro/17/05/04/opevl0383-luhut- tol-lauttekan-disparitas-harga-25-persen.

Pemerintah RI. 2015. Peraturan Menteri Perhubungan Nomor 93 Tahun 2013 tentang Penyelenggaraan Angukutan Laut. Jakarta (ID): Menteri Perhubungan.

Pemerintah RI. 2015. Peraturan Presiden Nomor 71 Tahun 2015 tentang Penetapan dan Penyimpanan Barang Kebutuhan Pokok dan Barang Penting. Jakarta (ID): Menteri Perhubungan.

Dewa S. 2016. Moda alternatif pada pendistribusian angkutan peti kemas di Pelabuhan Sukarno Hatta. Jurnal Riset dan Teknologi Kelautan (JRTK) 14 (1):141-150.

Tentang, C., \& Laut, T. (n.d.). Catatan Tentang Tol Laut Jokowi. 6989-7000.

Gultom, E. R. (n.d.). Merefungsi Pengangkutan Laut Indonesia melalui Tol Laut untuk Pembangunan Ekonomi Indonesia Timur.

Chandra, A. (2013). Analisis kinerja distribusi logistik pada pasokan barang dari pusat distribusi ke gerai indomaret di kota semarang. 